\title{
Medicinal Plants Used to Treat Neurological Disorders in West Africa: A Case Study with Guinea-Bissau Flora
}

\author{
Maria M. Romeiras ${ }^{1,2}$, Maria Cristina Duarte ${ }^{1,3}$, Bucar Indjai ${ }^{4}$, Luís Catarino ${ }^{1,3}$ \\ ${ }^{1}$ Instituto de Investigação Científica Tropical, Jardim Botânico Tropical, Travessa Conde da Ribeira 7, Lisboa, Portugal; \\ ${ }^{2}$ Universidade de Lisboa, BioFIG, Faculdade de Ciências, Campo Grande, Lisboa, Portugal; ${ }^{3}$ Universidade do Porto, CIBIO, Centro \\ de Investigação em Biodiversidade \& Recursos Genéticos, Vairão, Portugal; ${ }^{4}$ INEP, Instituto Nacional de Estudos e Pesquisa, Com- \\ plexo escolar 14 de Novembro, C.P. 112, Bissau, Guiné-Bissau. \\ Email: mromeiras@yahoo.co.uk
}

Received June $6^{\text {th }}, 2012$; revised July $2^{\text {nd }}, 2012$; accepted July $10^{\text {th }}, 2012$

\begin{abstract}
The sub-Saharan region holds a wide variety of indigenous plant species, still offering the possibility to discover very interesting new natural products with potential therapeutic value. Most of the African population depends on traditional medicine for primary health care, however, neurological disorders are often not considered as common diseases and many people with mental illnesses, like epilepsy, are severely affected by health-related stigma and discrimination. Epilepsy is the most common serious chronic brain disorder, estimated to affect at least 10 million people in Africa. Guinea-Bissau is located in West Africa, and its population is mainly rural with very few health services available. Since the earliest times, Guinea-Bissau flora has constituted the main source of materials used in folk medicine and the local population, who is well versed in the uses of these plants and their properties. The aim of this study was to document the existing knowledge and practices related to the treatment of neurological disorders, namely epilepsy and seizures, in Guinea-Bissau and in other West African countries. The results presented from this study provide information not only on the specific plants used to treat neurological disorders, but also on social knowledge brought in by various ethnic groups, each one having its own culture, beliefs and ways of nature appropriation. Taking into account the existing knowledge on the medicinal properties of plants for treatment of neurologic disorders, it is believed that research in the areas of ethnomedicine and ethnopharmacology in Guinea-Bissau can bring promising results capable of adding value to the very rich natural resources of this country of West Africa.
\end{abstract}

Keywords: West Africa; Medicinal Plants; Ethnobotany; Epilepsy; Guinea-Bissau

\section{Introduction}

Sub-Saharan Africa is rich in both biological and cultural diversity. Plant diversity is central to human wellbeing, especially in food production but also as a source of fiber for clothing, wood for implements, fuel, natural medicines and products, and also cultural and spiritual [1]. The sub-Saharan region still boasts a wide variety of indigenous plant species and it is still possible to discover new and very interesting natural products with potential therapeutic value [2]. According to the World Health Organization in some African countries, $80 \%$ of the population depends on traditional medicine for primary health care [3]. African folk medicine is a holistic discipline involving extensive use of indigenous herbalism combined with aspects of African spirituality [4]. In general, the traditional medicine encompasses the use of substances such as herbs, plants, animals and mineral elements, with dosages and practices based on sociocul- tural norms and religious beliefs as well as witnessed experiences and observation of a specific group, namely traditional healers [5-7].

The traditional healers provide a popular and accessible service, especially in the rural areas across the African continent where the sanitary situation is characterized by a lack of qualified health workers, medicines and equipment [8]. In general infectious diseases, such as malaria, AIDS, cholera, and tuberculosis are still common and are considered serious threats to public health [9-11]. As the access to conventional health care is often difficult, people use both conventional and traditional medicines to improve their health condition. So, the traditional medicine is an important element in the cultural patrimony and remains the main resource for the majority of people for treating health problems, particularly in rural areas [12]. However, neurological disorders are often not considered common diseases by most of the African population. Many people with mental illnesses, 
like epilepsy and other conditions, are severely affected by health-related stigma and discrimination.

Epilepsy is the most common serious chronic brain disorder, estimated to affect at least 50 million people in the world, of which 10 million live in Africa alone [3, 13,14]. In May 2000 Professionals from the Health, Social Sciences and Universities around Africa proclaimed the Africa declaration considering Epilepsy a health Priority in Africa [15]. However, progress has been slow with the treatment gap estimated to be around $80 \%$ to $85 \%$ especially due to: 1 ) lack of specialized personnel; 2) insufficiency of material; 3) lack of drugs or high cost; 4) cultural interpretation.

Guinea-Bissau is located in West Africa, and its borders are surrounded by the Republic of Senegal in the North, by the Republic of Guinea in the East and South, and by the Atlantic Ocean in the West. Geographically, Guinea-Bissau comprises a continental mainland and a group of 52 islands, the Bijagós Archipelago (Figure 1). According to the last National Census 2009 about 1.5 million inhabitants populated an area of $36.125 \mathrm{~km}^{2}$ [16]. The population is mainly rural and very few services are available to the people. Since earliest times Guinea-Bissau flora has constituted the main source of materials used in folk medicine. In general, all Guinea-Bissau population shows an extensive knowledge of plants and their properties. They maintain a deep relationship with the surrounding environment throughout their lives, using the natural resources to supply most of their needs. Nevertheless, the long-established knowledge of the medicinal properties of plants is nowadays under risk of disappearing, due to sociological changes that took place in the country over the last decades: namely the change of land usage, mainly through conversion of natural ecosystems to agricultural land and urban areas.
The Guinea-Bissau phytotherapeutic heritage was further developed and enriched by the knowledge brought in by various ethnic groups that migrated to this region from many areas, including Senegal, Sudan, and the Sahara region, e.g. Republic of Mali. Although Guinea-Bissau has a quite small territory, a large ethnical diversity was able to establish in this region, which is represented by approximately 30 groups (e.g. Balanta, Papel, Fula, Mandinga and Manjaco) each one having its own culture, beliefs and ways of nature appropriation. It must be noted that traditional healing methods are common and popular among Guinea-Bissau ethnic groups, particularly for treating people with mental disorders, but little information is available about the outcome of these traditional healing approaches. In Guinea-Bissau, there are no neuroscience personnel, and no brain diagnostic equipment [15]. Moreover, there is an almost absolute lack of trustworthy data available on neurological disorders and their incidence on the population of Guinea-Bissau. One of the few studies available was done by De Jong et al. [17], which performed an enquiry on the rural populations of Guinea-Bissau, concluding that the mental illnesses considered a priority in this country are psychoses, epilepsy and neuroses. Among the mental ailments referred to neuroses are the most frequently found, nevertheless there is a lack of attention when it comes to these patients. In that study, De Jong et al. [17] consider that any treatment program has to be carried out with the intimate collaboration of the family and of the most influential people of the village and the traditional healers. These healers were considered very important in the treatment of neurologic illnesses because they helped to prevent the exaggerated use of medication and helped to guarantee the treatment of latent psychosocial problems in the Guinea population.

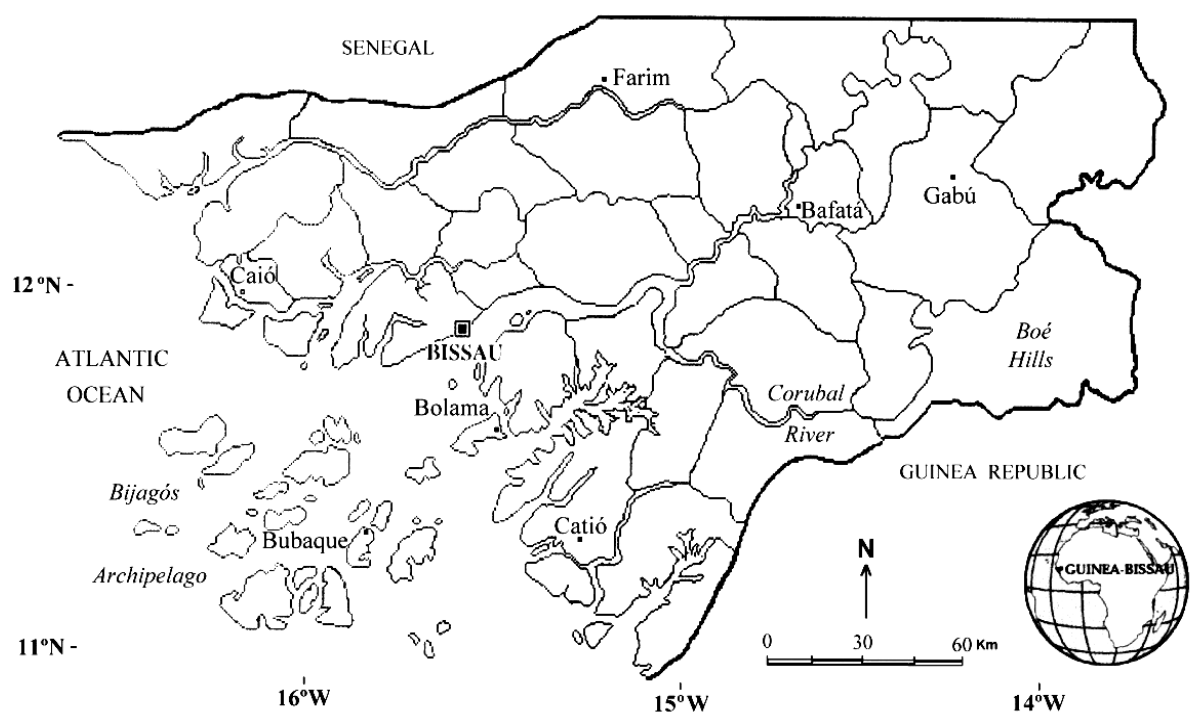

Figure 1. Map of Guinea-Bissau. 
This study was carried out to document herbal medicines used in the treatment of epilepsy and seizures, and to document the existing knowledge and practices related to this in Guinea-Bissau. It is intended to present some alternative forms of treatments, without resorting to medication and chemicals, having as a base the collection knowledge passed on from one generation to another. Therefore, a study centered on Guinea-Bissau is carried out here, and complemented by information obtained from neighboring countries, namely, Senegal, Gambia, Cameroon, with the objective to provide a global vision about the subject of medicinal plants and therefore contribute to transform popular knowledge into national resources, giving value to the flora in this region of West Africa [12,18-20].

\section{Materials and Methods}

For the present study research was done on the available information about medicinal plants commonly used for treatment of neurologic illnesses in West Africa, especially Guinea-Bissau, with particular attention on epilepsy and convulsions.

The ethnobotanical data were mainly obtained through a review conducted on several published works, that included references to the medicinal flora of Guinea-Bissau [21-24], and through the study of numerous specimens housed in Tropical Research Institute (LISC Herbarium), where the largest collection of specimens from GuineaBissau is found at a worldwide level.

Extensive fieldwork was carried out by some of the authors (Indjai and Catarino) over the last ten years in different regions of Guinea-Bissau. Ethnobotanical information (e.g. plants used in folk medicine) was documented during these surveys, which complement the inventory of the plant diversity of this country. In addition, two field expeditions were performed to Bijagós Archipelago (Figure 1), namely to Orango and Canhabaque Islands, in order to collect comprehensive data from traditional medicine practitioners on medicinal plants commonly used for treatment of neurologic disorders in Guinea-Bissau.

At the beginning of the fieldwork campaign, a meeting was held between the researchers, Bijagós Islands National Park staff members, and local community leaders, in order to: 1) explain the aim of the work and its integration in the Park activities; 2) get cooperation and permission to use the cultural heritage of Bijagós people; 3) select the informants according to their level of knowledge, age and gender; and 4) plan the field activities.

During the fieldwork in Orango Island (in the third quarter of 2007) and in Canhabaque Island (in the first quarter of 2012), twenty-six traditional medicine practitioners were selected as the best traditional knowledge holders. Semi-structured interviews were carried out in order to document the ethnomedicinal use of local flora. All of them agreed to participate and the interviews were performed in Creole, the vehicular language in the country. When needed, the translation to Bijagó, the language of the Bijagós ethnical group, was made with the support of the Orango Park staff. Data collected during the fieldwork included: applications and parts of the plant used; methods of preparation and administration routes; and common and local name of the plant. It must be pointed out that the authors have a deep knowledge of local flora and during the fieldwork a member of the study team (Indjai) served as an interpreter when necessary. At the end of each interview, voucher specimens of plants mentioned by the interviewees were collected. The plants were identified by staff at the LISC Herbarium of the Tropical Research Institute, Lisbon (Portugal).

All the information obtained for Guinea-Bissau was further complemented by investigation of the information on the medicinal species used to treat epilepsy and convulsions in West Africa. For this purpose some published works [e.g. 25-27] and the database PROTA [28] were consulted.

\section{Results and Discussion}

Recent trends in research into African plant uses, show that traditional medicine is commonly used to treat neurological disorders in the West African region, and some recent publications are available, namely for Nigeria [29], Gambia [30], Senegal [31], and Cameroon [26,32]. However, there are still very few studies on this subject for Guinea-Bissau [17].

For the West African countries considered in our study, a total of 67 plant species, distributed over 55 genera and 32 families were reported as used to treat neurological and mental disorders (Table 1). From these, 54 are woody plants and 13 are herbs. Most of the woody plants used are trees and shrubs (29 and 13 species, respectively), but six species of subshrubs and six species of lianas and climbers are also used. Among the herbaceous species used eight are annual and five are perennial. The best represented families are Fabaceae (18 species), Euphorbiaceae ( 7 species) and Apocynaceae (4 species).

When it comes to the geographic distribution of the species used in traditional medicine in West Africa to treat epilepsy and other neurological disorders, 56 species are native and 11 are introduced, of which, 8 are grown and 3 are found naturalized. The native species are mainly of tropical African distribution (38 species), 11 are paleotropical plants, 6 pantropical plants and one with an Afro-American distribution.

From the 67 species (see Table 1), 53 are used in Guinea-Bissau for several medicinal purposes and non- 
Table 1. Medicinal plants of Guinea-Bissau flora reported as used in neurological disorders in West Africa and in GuineaBissau.

\begin{tabular}{|c|c|c|c|c|c|c|}
\hline Species & Family & Habit & Distribution & $\begin{array}{l}\text { Medicinal and other uses } \\
\text { in Guinea-Bissau }\end{array}$ & $\begin{array}{l}\text { Neurological uses in } \\
\text { West Africa }^{\mathrm{b}}\end{array}$ & Source $^{c}$ \\
\hline Abrus precatorius L. & Fabaceae & climber & Pantropical & other medicinal uses & convulsions & 22,25 \\
\hline $\begin{array}{l}\text { Acalypha villicaulis Hochst. ex A. } \\
\text { Rich. }\end{array}$ & Euphorbiaceae & subshrub & African & & epilepsy & 28 \\
\hline $\begin{array}{l}\text { Alchornea cordifolia (Schumach. } \\
\text { \& Thonn.) Muell. Arg. }\end{array}$ & Euphorbiaceae & shrub & African & other medicinal uses & epilepsy & 22,28 \\
\hline Alstonia boonei De Wild. & Apocynaceae & tree & African & other medicinal uses; wood & depressant & 22,27 \\
\hline Amaranthus viridis L. & Amaranthaceae & annual herb & Pantropical & & convulsions, epilepsy & 28 \\
\hline Anacardium occidentale L. & Anacardiaceae & tree & America $^{\mathrm{a}}$ & other medicinal uses; food & depressant & 22,27 \\
\hline Andira inermis (Wright) DC. & Fabaceae & tree & African & & depressant & 27 \\
\hline Annona senegalensis Pers & Annonaceae & shrub & African & other medicinal uses; food & convulsions, epilepsy & 22,26 \\
\hline $\begin{array}{l}\text { Asystasia gangetica }(\mathrm{L} .) \mathrm{T} \text {. } \\
\text { Anderson ex Thwaites }\end{array}$ & Acanthaceae & annual herb & Paleotropical & other medicinal uses & epilepsy & 22,28 \\
\hline Bersama abyssinica Fresen & Melianthaceae & tree & African & & epilepsy & 28 \\
\hline Blighia sapida Koenig & Sapindaceae & tree & African & other medicinal uses; food & convulsions, epilepsy & 22,25 \\
\hline Boerhavia diffusa L. & Nyctaginaceae & $\begin{array}{l}\text { perennial } \\
\text { herb }\end{array}$ & Pantropical & & convulsions & 25 \\
\hline Cajanus cajan (L.) Millsp. & Fabaceae & shrub & India $^{a}$ & food & epilepsy & 22,28 \\
\hline $\begin{array}{l}\text { Calycobolus heudelotii (Bak. } \\
\text { ex Oliv.) Heine }\end{array}$ & Convolvulaceae & liana & African & $\begin{array}{l}\text { seizures, other medicinal } \\
\text { uses }\end{array}$ & & 22 \\
\hline Cassia sieberiana DC. & Fabaceae & tree & African & $\begin{array}{l}\text { witchcraft, Irans; other } \\
\text { medicinal uses }\end{array}$ & & 23 \\
\hline Citrus sinensis (L.) Osbeck. & Rutaceae & tree & Asia $^{a}$ & food & convulsions, epilepsy & 22,26 \\
\hline $\begin{array}{l}\text { Cochlospermum tinctorium } \\
\text { Perr. Ex A. Rich. }\end{array}$ & Cochlospermaceae & subshrub & African & other medicinal uses & epilepsy & 22,28 \\
\hline $\begin{array}{l}\text { Cryptolepis sanguinolenta (Lindl.) } \\
\text { Schltr. }\end{array}$ & Apocynaceae & climber & African & $\begin{array}{l}\text { witchcraft, bad spirits; } \\
\text { other medicinal uses }\end{array}$ & & 23 \\
\hline $\begin{array}{l}\text { Daniellia oliveri (Rolfe) Hutch. \& } \\
\text { Dalz. }\end{array}$ & Fabaceae & tree & African & other medicinal uses & epilepsy & 22,26 \\
\hline $\begin{array}{l}\text { Desmodium adscendens (Sw.) } \\
\text { DC. }\end{array}$ & Fabaceae & $\begin{array}{l}\text { annual } \\
\text { herb }\end{array}$ & Afro-American & & convulsions & 25 \\
\hline $\begin{array}{l}\text { Detarium microcarpum Guill. \& } \\
\text { Perr. }\end{array}$ & Fabaceae & tree & African & other medicinal uses & epilepsy & 22,26 \\
\hline $\begin{array}{l}\text { Erythrophleum africanum } \\
\text { (Benth.) Harms }\end{array}$ & Fabaceae & tree & African & & epilepsy & 28 \\
\hline $\begin{array}{l}\text { Erythrophleum suaveolens (Guill. } \\
\text { \& Perr.) Brenan }\end{array}$ & Fabaceae & tree & Paleotropical & wood, phytochemical & convulsions & 22,25 \\
\hline Euphorbia hirta L. & Euphorbiaceae & annual herb & America $^{a}$ & & convulsions & 26 \\
\hline Ficus lutea Vahl & Moraceae & tree & African & $\begin{array}{l}\text { seizures; other medicinal } \\
\text { uses; phytochemical }\end{array}$ & & 22 \\
\hline Ficus sur Forssk. & Moraceae & tree & African & other medicinal uses; food & epilepsy & 22,25 \\
\hline Flacourtia indica (Burm.f.) Merr. & Flacourtiaceae & tree & Paleotropical & & epilepsy & 26 \\
\hline Guiera senegalensis J. F. Gmel. & Combretaceae & shrub & African & $\begin{array}{l}\text { other medicinal uses; } \\
\text { rituals }\end{array}$ & depressant & 22,27 \\
\hline
\end{tabular}




\section{Continued}

\begin{tabular}{|c|c|c|c|c|c|c|}
\hline Hoslundia opposita Vahl & Labiatae & shrub & African & & epilepsy & 25 \\
\hline Hymenocardia acida Tul. & Euphorbiaceae & tree & African & other medicinal uses & epilepsy & 22, 26 \\
\hline $\begin{array}{l}\text { Indigofera arrecta Hochst. ex A. } \\
\text { Rich. }\end{array}$ & Fabaceae & subshrub & Paleotropical & phytochemical & epilepsy & 22,28 \\
\hline Indigofera tinctoria $\mathrm{L}$. & Fabaceae & subshrub & Paleotropical & phytochemical & epilepsy & 22,28 \\
\hline Jatropha curcas L. & Euphorbiaceae & shrub & America $^{\mathrm{a}}$ & $\begin{array}{l}\text { other medicinal uses; } \\
\text { phytochemical }\end{array}$ & convulsions & 22,25 \\
\hline Jatropha gossypifolia L. & Euphorbiaceae & shrub & America $^{\mathrm{a}}$ & other medicinal uses & convulsions & 22, 26 \\
\hline $\begin{array}{l}\text { Khaya senegalensis (Desr.) A. } \\
\text { Juss. }\end{array}$ & Meliaceae & tree & African & other medicinal uses & depressant & 22,27 \\
\hline Landolphia heudelotii A. DC. & Apocynaceae & liana & African & $\begin{array}{l}\text { "mental problems"; other } \\
\text { medicinal uses; food }\end{array}$ & & 22 \\
\hline Lannea velutina A. Rich. & Anacardiaceae & tree & African & food & epilepsy and insanity & 22,28 \\
\hline Leea guineensis G. Don & Leeaceae & shrub & African & & epilepsy & 25 \\
\hline $\begin{array}{l}\text { Leptoderris brachyptera (Benth.) } \\
\text { Dunn. }\end{array}$ & Fabaceae & liana & African & seizures & & 22 \\
\hline $\begin{array}{l}\text { Lonchocarpus sericeus (Poir.) } \\
\text { Kunth }\end{array}$ & Fabaceae & tree & African & other medicinal uses & convulsions & 22,25 \\
\hline Mangifera indica $L$. & Anacardiaceae & tree & Indiaa & $\begin{array}{l}\text { "diseases of unknown } \\
\text { origin" }\end{array}$ & & 21 \\
\hline $\begin{array}{l}\text { Maytenus senegalensis (Lam.) } \\
\text { Exell }\end{array}$ & Celastraceae & shrub & African & child convulsions & & 22 \\
\hline $\begin{array}{l}\text { Microglossa pyrifolia (Lam.) } \\
\text { Kuntze }\end{array}$ & Compositae & shrub & Paleotropical & & epilepsy & 25 \\
\hline Morinda geminata DC. & Rubiaceae & tree & African & $\begin{array}{l}\text { "bad winds"; other } \\
\text { medicinal uses }\end{array}$ & & 23 \\
\hline Musa sapientum $\mathrm{L}$. & Musaceae & $\begin{array}{l}\text { perennial } \\
\text { herb }\end{array}$ & Asia & food & epilepsy & 22,25 \\
\hline $\begin{array}{l}\text { Newbouldia laevis (P. Beauv.) } \\
\text { Seeman }\end{array}$ & Bignoniaceae & tree & African & other medicinal uses & convulsions, epilepsy & 22,25 \\
\hline Nymphaea lotus L. & Nymphaeaceae & $\begin{array}{l}\text { perennial } \\
\text { herb }\end{array}$ & Paleotropical & food & depressant & 22,27 \\
\hline Ocimum gratissimum L. & Labiatae & subshrub & Asia & "bad spirits" & & 21,24 \\
\hline $\begin{array}{l}\text { Palisota hirsuta (Thunb.) K. } \\
\text { Schum. ex Engl. }\end{array}$ & Commelinaceae & $\begin{array}{l}\text { perennial } \\
\text { herb }\end{array}$ & African & other medicinal uses & epilepsy & 22,25 \\
\hline Passiflora foetida $\mathrm{L}$. & Passifloraceae & annual herb & Asia & food & depressant & 22,27 \\
\hline Piper guineense Schum. \& Thonn. & Piperaceae & liana & African & other medicinal uses & depressant & 22, 24 \\
\hline $\begin{array}{l}\text { Prosopis africana (Guill. \& Perr.) } \\
\text { Taub }\end{array}$ & Fabaceae & tree & African & other medicinal uses; wood & epilepsy & 22, 26 \\
\hline Psidium guajava L. & Myrtaceae & tree & America & other medicinal uses; food & convulsions, epilepsy & 22,25 \\
\hline $\begin{array}{l}\text { Psorospermum corymbiferum } \\
\text { Hochr. }\end{array}$ & Guttiferae & shrub & African & $\begin{array}{l}\text { "bad winds, evil spirits"; } \\
\text { other medicinal uses }\end{array}$ & & 23 \\
\hline $\begin{array}{l}\text { Psychotria peduncularis (Salisb) } \\
\text { Steyerm }\end{array}$ & Rubiaceae & shrub & African & $\begin{array}{l}\text { "bad spirits, mandjidura” } \\
\text { (witchcraft) }\end{array}$ & & 21 \\
\hline Rauvolfia vomitoria Afzel. & Apocynaceae & tree & African & other medicinal uses & convulsions & 22,25 \\
\hline Ricinus communis L. & Euphorbiaceae & $\begin{array}{l}\text { perennial } \\
\text { herb }\end{array}$ & Paleotropical & $\begin{array}{l}\text { other medicinal uses; } \\
\text { ornamental }\end{array}$ & epilepsy & 22,25 \\
\hline
\end{tabular}




\begin{tabular}{|c|c|c|c|c|c|c|}
\hline \multicolumn{7}{|l|}{ Continued } \\
\hline $\begin{array}{l}\text { Securidaca longipedunculata } \\
\text { Fresen. }\end{array}$ & Polygalaceae & tree & African & $\begin{array}{l}\text { "bad spirits"; } \\
\text { phytochemical }\end{array}$ & convulsions & $22,23,25$ \\
\hline Senna occidentalis (L.) Link. & Fabaceae & annual herb & Pantropical & other medicinal uses; food & convulsions & 22,25 \\
\hline Syzygium guineense (Will.) DC. & Myrtaceae & tree & Paleotropical & & epilepsy & 28 \\
\hline $\begin{array}{l}\text { Tetrapleura tetraptera } \\
\text { (Schumach. \& Thonn.) Taub. }\end{array}$ & Fabaceae & tree & African & & epilepsy & 26 \\
\hline Trichilia emetica Vahl & Meliaceae & tree & Paleotropical & other medicinal uses & epilepsy & 22,26 \\
\hline Uvaria chamae P. Beauv. & Annonaceae & shrub & African & $\begin{array}{l}\text { epilepsy, "bad winds, bad } \\
\text { spirits"; food }\end{array}$ & & 21,24 \\
\hline Vigna subterranea (L.) Verdc. & Fabaceae & annual herb & Paleotropical & food & epilepsy & 22,28 \\
\hline Vigna unguiculata (L.) Walp. & Fabaceae & annual herb & Pantropical & food & epilepsy & 22,28 \\
\hline Vitellaria paradoxa C. F. Gaertn. & Sapotaceae & tree & African & food & convulsions, epilepsy & 22,26 \\
\hline Waltheria indica L. & Sterculiaceae & subshrub & Pantropical & other medicinal uses & depressant & 22,27 \\
\hline
\end{tabular}

${ }^{\mathrm{a}}$ Non-native species, introduced and cultivated in Guinea-Bissau; ${ }^{\mathrm{b}}$ Plants used as antiepileptic, anticonvulsant and depressant in West Africa; ${ }^{\mathrm{C}}$ Sources according to the References section.

medicinal purposes (e.g. food, fibers, phytochemical use, and wood). Of these, 41 have a medicinal use in the country, however only 14 were reported to be used in the treatments of mental issues in a wide-ranging mode. Nevertheless, among these species, only one (Securidaca longipedunculata-Figure 2(a)) was mentioned in the West African publication consulted. Several factors can contribute to the relatively low number of references to medicinal plants for the treatment of mental issues. In fact, during the fieldwork performed by some of the authors in rural areas of Guinea-Bissau, it was possible to verify that, with some exceptions (e.g. Uvaria chamaeFigure 2(b)); the neurologic illnesses are rarely mentioned by the healers during interviews. In many cases the neurologic illnesses are attributed to unknown causes or to supernatural causes, and often only the symptoms are referred to, for example: convulsions, insanity or strong headaches. Furthermore, in one of the few available studies [33], it is referenced that in Guinea-Bissau, the large majority of people that go to hospitals and health centres, do so in parallel with the traditional medicine practitioners, which have a great influence both in the behavior and the thought process of the Guinea-Bissau citizens. On the other hand there is a great lack of formal structure, while the traditional medicine depends only on the local resources available that leads to the fact that local healers have a very important role in the provision of health services in the population of Guinea-Bissau, particularly in the rural areas.

During the interviews with traditional medicine practitioners as part of the fieldwork to collect ethnobotanical data, it was possible to identify two main different types of practices in traditional medicine: one takes into account
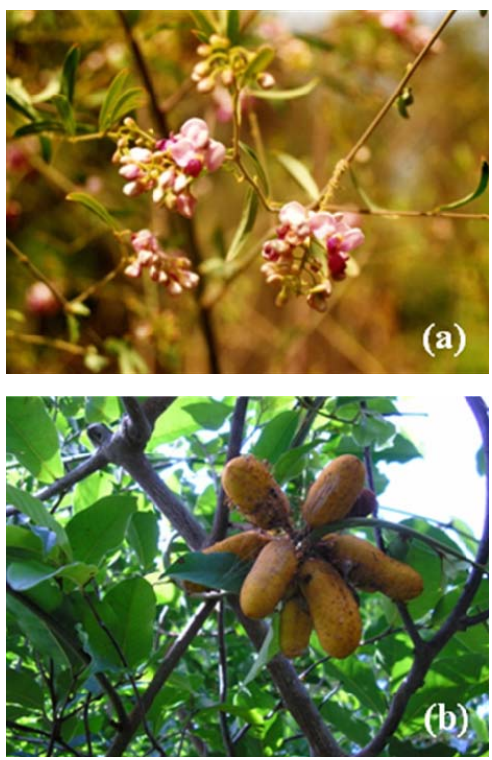

Figure 2. Two plants used to treat neurological disorders in Guinea-Bissau. (a) Securidaca longipedunculata; (b) Uvaria chamae.

the knowledge of the medicinal properties of plants and other therapeutic techniques, without resource to rituals or prayers; the other type of therapeutic practice resorts to aspects of spirituality and combines the use of medicinal plants with rituals and prayers.

These results are in agreement with the ethnomedical classification used by Mencagli [34], which considered that the traditional healers are divided into three main categories: 1) specialists in medicinal plants and/or some specific techniques (bone repairmen, dentists, matrons, specialist massage and application of horns); 2) experts 
on religion and healing with ceremonies (djambacosses, balobeiros, marabouts, mouros) acting as mediums of Irans (spirits); 3) experts who do a combination of the above specialties (commonly named curandeiros).

In Guinea-Bissau, neurological disorders are thought to be caused by many different factors such as evil spirits (Irans, as known in the country) or witchcraft. As in other African countries, treatment by traditional healers is in keeping with this and includes the wearing of amulets, drinking of herbal remedies, bathing in decoctions or infusions made with specific roots and leaves, and giving out charity or local treatments [35].

This way, for many ethnical groups interviewed in Guinea-Bissau, neurologic illnesses in general and epilepsy in particular are attributed to possessions by spirits termed locally as "Irans", leaving the victim vulnerable to attacks at any moment and therefore leaving the physical integrity of the individual susceptible. Another cause found during the fieldwork, for the neurologic and mental disturbances is related to witchcraft, referred locally as "manjidura". When an epilepsy attack occurs people are reluctant to act promptly because they fear the reactions of the Iran, which increases the strength of the victim during the epilepsy attack and can cause the aiding person to get hurt.

Beyond everything that was previously mentioned, there is also the difficulty that health technicians have to diagnose the patients that suffer from neurological disorders sensu lato, because in the majority of the cases they show other symptoms, such as headaches and body pains, fevers and convulsions, weakness and pains in the upper and lower limbs. That often implies that healers do not recognize those disorders as neurologic in nature, that maybe one of the contributing reasons for the fact that only a few numbers of plants are reported for these ends in Guinea-Bissau. According to De Jong et al. [17], the disorders of neurologic nature are recognized with difficulty by the health technicians, and often there is a high level of passivity that contributes to the fact that patients remain with no means of medical assistance, especially in the rural areas of Guinea-Bissau.

The fact that this is a country where the majority of the rural areas do not have running water or electricity, where homes are mud huts and thatch-roofed, and the majority of the population does not have a regular education, allows for the possibility of an extensive knowledge of the usage of plants to heal the main illnesses. In this scope, it must be mentioned that during the fieldwork, the most mentioned disorders where malaria, breathing infections, diarrheas, skin disorders, tuberculosis or AIDS, were also confirmed during the exhaustive bibliographic research on this subject $[22,24]$.

As was mentioned previously many other questions related to anthropologic reasons must be, in future works, considered, so that a global vision of the treatment of neurologic disorders in Guinea-Bissau is achieved. Our study was done mainly around botanical and biological questions and the majority of the fieldwork and the interviews focused on the healers, due to the fact that they are the ones using the plants, referring the parts used, application and preparation, but little reference to the religious side of the matter. However epilepsy as well as other mental issues is frequently treated by the djambacosses that use religion and other ritual practices to heal these disorders. The few djambacosses that were interviewed were not very receptive to pass-on this type of information which can hide the few plants that are mentioned by citizens of Guinea-Bissau to cure neurological disorders, contrary to what happens in neighboring countries of West Africa.

\section{Conclusions}

Even though the existing data for Guinea-Bissau is limited and old, the extent of mental issues in the country was assessed to be around $12 \%$ [36], which makes it a potentially very serious public health issue. Nevertheless the majority of the cases remain undetected and untreated, both by the health services and traditional medicine. On the other hand the neurologic disorders are looked at by the public as a result of occult forces or witchcraft, which does not help a correct diagnosis and correct treatment for these types of problems.

It is therefore important to promote clarity of the general local public, particularly the practitioners of traditional medicine, on the causes, symptoms, and the possibilities of treatments for the neurologic disorders. This would help to demystify the neurologic and mental disorders, decrease the isolation and exclusion of the patients suffering these types of disorders and promote an adequate treatment whenever possible. The health services in Guinea-Bissau are very basic, particularly in the rural areas; therefore a better collaboration between the traditional medicine and the official medicine can help to solve a significant part of the serious health issues faced by the local communities.

Regarding the plants being used by the traditional medicine for treatment of neurologic disorders it may be possible to obtain a validation for many of their uses by pharmacologic tests, as has already happened with other types of plant uses by the traditional medicine in GuineaBissau [37-39]. Validations could be followed by toxicology and dosage tests with a view to return the knowledge to the populations. Taking into account the existing knowledge in the country on the medicinal properties of plants, it is believed that research in the area of ethnomedicine and ethnopharmacology in Guinea-Bissau must proceed in order to bring about promising results 
that can add value to the very rich natural resources of this country of West Africa.

\section{Acknowledgements}

The fieldwork made by B. I. was supported by the Institute for Biodiversity and Protected Areas (IBAP) of Guinea-Bissau. The authors are very grateful to Dr. Luísa Nunes for the critical reading of the manuscript and to Philip Havik and Dora Castro from IICT. The study was supported by Portuguese FCT grants: to MMR and MCD [HC/0075/2009]; to LC [AFR/117785/2010].

\section{REFERENCES}

[1] B. D. McIntyre, H. R. Herren, J. Wakhungu and R. T. Watson, "Agriculture at a Crossroads-International Assessment of Agricultural Knowledge, Science and Technology for Development: Sub-Saharan Africa Report,” Island Press, Washington DC, 2009.

[2] K. Hostettmann, A. Marston, K. Ndjoko and J.-L. Wolfender, "The Potential of African Plants as a Source of Drugs,” Current Organic Chemistry, Vol. 4, No. 10, 2000, pp. 973-1010. doi:10.2174/1385272003375923

[3] World Health Organization, "Health Situation Analysis in the African Region, Atlas of Health Statistics, 2011," WHO Regional Office for Africa, Brazzaville, 2011.

[4] M. M. Tabi, M. Powel and D. Hodnicki, "Use of Traditional Healers and Modern Medicine in Ghana,” International Nursing Review, Vol. 53, No. 1, 2006, pp. 52-58. doi:10.1111/j.1466-7657.2006.00444.x

[5] S. Baldé and C. Sterck, "Traditional Healers in Casamance, Senegal," World Health Forum, Vol. 15, No. 4, 1994, pp. 390-392.

[6] P. P. Mhame, K. Busia and O. M. J. Kasilo, "Clinical Practices of African Traditional Medicine," The African Health Monitor, Special Issue 14, 2010, pp. 32-39.

[7] World Health Organization, "WHO Traditional Medicine Strategy 2002-2005,” WHO, Geneva, 2002.

[8] K. Inngjerdingen, C. S. Nergard, D. Diallo, P. P. Mounkoro and B. S. Paulsen, "An Ethnopharmacological Survey of Plants Used for Wound Healing in Dogonland, Mali, West Africa," Journal of Ethnopharmacology, Vol. 92, No. 2-3, 2004, pp. 233-244. doi:10.1016/j.jep.2004.02.021

[9] M. Bjerregaard-Andersen, Z. J. da Silva, P. Ravn, M. Ruhwald, P. L. Andersen, M. Sodemann, P. Gustafson, P. Aaby and C. Wejse, "Tuberculosis Burden in an Urban Population: A Cross Sectional Tuberculosis Survey from Guinea Bissau,” BMC Infectious Diseases, Vol. 10, No. 1, 2010, p. 96. doi:10.1186/1471-2334-10-96

[10] R. Colombatti, C. S. Vieira, F. Bassani, R. Cristofoli, A. Coin, L. Bertinato and F. Riccardi, "Contamination of Drinking Water Sources During the Rainy Season in an Urban Post-Conflict Community in Guinea Bissau: Implications for Sanitation Priority," African Journal of Medicine \& Medical Sciences, Vol. 38, No. 2, 2009, pp. 155161.
[11] O. Larsen, Z. da Silva, A. Sandström, P. K. Andersen, S. Andersson, A.-G. Poulsen, M. Melbye, F. Dias, A. Nauclér and P. Aaby, "Declining HIV-2 Prevalence and Incidence among Men in a Community Study from GuineaBissau,” AIDS, Vol. 12, No. 13, 1998, pp. 1707-1714.

[12] E. Rukangira, "Medicinal Plants and Traditional Medicine in Africa: Constraints and Challenges," Sustainable Development International, Vol. 4, 2001, pp. 179-184.

[13] A. Okasha, "Mental Health in Africa: The Role of the WPA,” World Psychiatry, Vol. 1, No. 1, 2002, pp. 32-36.

[14] R. A. Scott, S. D. Lhatoo and J. W. Sander, "The Treatment of Epilepsy in Developing Countries: Where Do We Go from Here?” Bulletin of the World Health Organization, Vol. 79, No. 4, 2001, pp. 344-351.

[15] World Health Organization, "Epilepsy in the WHO African Region: Bridging the Gap,” WHO Regional Office for Africa, Brazzaville, 2004.

[16] Instituto Nacional de Estatística, "Guine Bissau-Recenseamento Geral da População e Habitação 2009,” INE, Bissau, 2009.

[17] J. De Jong, G. Klein and S. Horn, "Estudo Básico sobre Perturbações Mentais no País,” Soronda-Revista de Estudos Guineenses, No. 4, 1987, pp. 113-132.

[18] A. B. Cunningham, “African Medicinal Plants: Setting Priorities at the Interface between Conservation and Primary Health Care,” People and Plants Working Paper 1, UNESCO, Paris, 1993.

[19] T. Etonde and E. Malobe, "Nos Plantes qui nos Soignent," Centre Spirituel de Rencontre, Douala, 2003.

[20] E. T. Gomes, O. Silva, M. A. Diniz and E. S. Martins, "Plantas Medicinais da Guiné-Bissau-Manual Prático," ACEP/AD, Lisboa/Bissau, 2003.

[21] A. V. M. Campos and B. Indjai, "Projecto Inventario das Plantas Medicinais da Ilha de Bubaque, Reserva da Biosfera do Arquipélago Bolama Bijagós, Guiné-Bissau, Relatório de Actividades,” INEP, Bissau, 1996.

[22] L. Catarino, E. S. Martins, M. F. Pinto-Basto and M. A. Diniz, "Plantas Vasculares e Briófitos da Guiné-Bissau," IICT/IPAD, Lisboa, 2006.

[23] B. Indjai, "Plantas Medicinais Comercializadas nos Mercados de Bissau. Subsidio para o Sistema Nacional de Saúde Pública e Contribuição para o Conhecimento da Flora Medicinal Guineense e sua Conservação,” INEP/ CEATA/SWISSAID, Bissau, 2003.

[24] B. Injai, L. Catarino and D. Mourão, "Mezinhos de Orango -Plantas Medicinais e Pessoas da Ilha da Rainha Pampa," IBAP, Bissau, 2010.

[25] E. S. Ayensu, "Medicinal Plants of West Africa,” Reference Publications Inc., Algonac Michigan, 1978.

[26] E. N. Bum, G. S. Taiwe, F. C. O. Moto, G. T. Ngoupaye, R. R. N. Vougat, V. D. Sakoue, C. Gwa, E. R. Ayissi, C. Dong, A. Rakotonirina and S. V. Rakotonirina, “Antiepileptic Medicinal Plants Used in Traditional Medicine to Treat Epilepsy,” In: Z. Afawi, Ed., Clinical and Genetic Aspects of Epilepsy, Intech, Rijeka, 2011, pp. 175-192.

[27] B. Oliver-Bever, "Medicinal Plants in Tropical West Africa,” Cambridge University Press, Cambridge, 1986. 
[28] PROTA, “Plant Resources of Tropical Africa,” 2012. http://www.prota4u.info/

[29] M. Kabir, Z. Iliyasu, I. S. Abubakar, Z. S. Kabir and A. U. Farinyaro, "Knowledge, Attitude and Beliefs about Epilepsy among Adults in a Northern Nigerian Urban Community," Annals of African Medicine, Vol. 4, No. 3, 2005, pp. 107-112.

[30] R. Coleman, L. Loppy and G. Walraven, "The Treatment Gap and Primary Health Care for People with Epilepsy in Rural Gambia,” Bulletin of the World Health Organization, Vol. 80, No. 5, 2002, pp. 378-383.

[31] N. F. Ndoye, A. D. Sow, A. G. Diop, B. Sessouma, F. Séne-Diouf, L. Boissy, I. Wone, K. Touré, M. Ndiaye, P. Ndiaye, H. de Boer, J. Engel, C. Mandlhate, H. Meinardi, L. Prilipko and J. W. Sander, "Prevalence of Epilepsy Its Treatment Gap and Knowledge, Attitude and Practice of Its Population in Sub-Urban Senegal an ILAE/IBE/WHO Study," Seizure, Vol. 14, No. 2, 2005, pp. 106-111. doi:10.1016/j.seizure.2004.11.003

[32] E. Noumi and F. L. Fozi, "Ethnomedical Botany of Epilepsy treatment in Fongo-Tongo Village, Western Province, Cameroon,” Pharmaceutical Biology, Vol. 41, No. 5, 2003, pp. 330-339.

[33] E. Crowley and R. Ribeiro, "Sobre a Medicina Tradicional e Forma da sua Colaboração com a Medicina Moderna,” Soronda-Revista de Estudos Guineenses, No. 4, 1987, pp. 95-112.

[34] K. A. Mencagli “Medicina Tradicional,” Boletim da Diocese de Bissau, No. 4, 1992, pp. 1-404.

[35] S. Campbell, "Traditional Medicine in the Gambia," Complementary Therapies in Nursing and Midwifery, Vol. 3, No. 4, 1997, pp. 103-105. doi:10.1016/S1353-6117(97)80061-3

[36] J. De Jong, G. Klein and S. Horn, "Estudo sobre Perturbações Mentais na Guiné-Bissau,” Jornal Brasileiro de Psiquiatria, Vol. 40, No. 2, 1991, pp. 79-88.

[37] P. M. Abreu, E. S. Martins, O. Kayser, K.-U.Bindseil, K. Siems, A. Seeman and J. Frevert, "Antimicrobial, Antitumor and Antileishmania Screening of Medicinal Plants from Guinea-Bissau,” Phytomedicine, Vol. 6, No. 3, 1999, pp. 187-195. doi:10.1016/S0944-7113(99)80008-7

[38] O. Silva, A. Duarte, J. Cabrita, M. Pimentel, A. Diniz and E. T. Gomes, "Antimicrobial Activity of Guinea-Bissau Traditional Remedies,” Journal of Ethnopharmacology, Vol. 50, No. 1, 1996, pp. 55-59. doi:10.1016/0378-8741(95)01323-7

[39] O. Silva, E. Ferreira, M. V. VazPato and E. Gomes, "Guinea-Bissau's Plants in Vitro Susceptibility Studies on Neisseria gonorrhoeae," International Journal of Pharmacognosy, Vol. 35, No. 5, 1997, pp. 323-328. 